Oral presentation

\title{
The practice of physical restraint in the UK Peter Lepping
}

Address: North East Wales NHS Trust, Ffordd Croesnewydd, Wrexham, LL13 7TD, UK

from WPA Thematic Conference. Coercive Treatment in Psychiatry: A Comprehensive Review

Dresden, Germany. 6-8 June 2007

Published: 19 December 2007

BMC Psychiatry 2007, 7(Suppl I):S6I doi:I0.1 186/I47I-244X-7-SI-S6I

This abstract is available from: http://www.biomedcentral.com/I47I-244X/7/SI/S6 I

(C) 2007 Lepping; licensee BioMed Central Ltd.

\section{Background}

To give an overview of coercive measures in the UK and present data relating to coercive measures in the Wrexham Maelor Hospital in Wales.

\section{Methods}

Audit data presentation and overview.

\section{Results}

Coercion in the UK is primarily done by control and restraint procedures, which may lead to the application of medication (chemical restraint). Mechanical restraint is not used at all in adult psychiatry. Overall incidences of coercive measures are less frequent and less long than in equivalent German hospitals.

\section{Conclusion}

It is possible to run adult psychiatric wards without longterm mechanical restraint. 